\title{
FINANCIAL MANAGEMENT AND ACCOUNTING PRACTICES OF MICRO AND SMALL ENTERPRISES (MSES) IN MANIPUR
}

\author{
*Jangkholam \\ *Research Scholar,Department of Commerce, Manipur University \\ **A. Rajmani Singh \\ **Professor, Department of Commerce, Manipur University
}

\begin{abstract}
Micro and Small Enterprises are a very important sector that continues to contribute enormously for the economic development of the country and to the state of Manipur in particular. The success and failure of these enterprises depends a lot on the efficient management of its financial resources. This paper therefore attempts to study the accounting and financial management practices followed by the Micro and Small Enterprises (MSEs) in Manipur and to make an awareness about the importance of accounting and financial management practices in their business conduct. For the purpose of the study both primary and secondary data are used. Secondary data were collected from the related available literature like books, articles, magazines, MSME annual report, directory of MSME Manipur, etc. Primary data is obtained by distributing questionnaire to 100 respondents who are owner/manager of the MSEs. The collected data were analysed using various statistical tools to get meaningful conclusion. The results of the study revealed that majority of the MSEs do not maintain proper accounting records of their business which made it difficult for the owner-manager to measure the performance of their business. The main reason for the failure of the enterprises to keep proper accounting records is their lack of knowledge in accounting. The financial management practices followed by the MSES in Manipur are only fire-fighting in nature and no standard rules or procedures are followed for managing their finance. Finally, the study suggested that both the Central and the State Government should make strict rules and regulations to adopt accounting and financial management practices to each and every MSEs operating in the state.
\end{abstract}

KEYWORDS: Accounting practices, Accounting records, Financial management, Micro and Small Enterprises (MSEs), Manipur.

\section{INTRODUCTION}

Micro Small and Medium Enterprises (MSMEs) play a very important role in the economic development of a country. MSMEs are capable of creating jobs with small amount of capital and in dispersed locations which makes it attractive to policy makers. The sector constitutes the second largest employment provider next to the agricultural sector. World over, half to two-thirds of all businesses are MSMEs and in many regions this proportion is much higher. In India, MSMEs are the second largest source of employment next only to agriculture.

(Lalhriatchhungi \& Prasain, 2017). The sector account for a major share of production and export. It helps the Indian economy tremendously by providing large employment opportunities, industrializing the rural and backward areas, bringing an equitable distribution of national income and wealth and also contributing to the socio-economic development of the country. The sector also contributed to the GDP of the country. Effective utilisation of locally available resources, lower investment requirements, operational flexibility and high rate of innovations are the advantages of the MSME sector. The government has extended various kinds of help to the MSMEs for their development and betterment. The Government passed the MSME Development Act, 2006 after realising the importance and contribution the MSME made to the economy. Various committees have been formed and also various research have been conducted for the improvement of the MSMEs. However, the sector continues to face various problems and hurdles which include obtaining the required finance, problems of raw-materials, problems of inadequate accounting practices, etc. Among the various problems faced by 
the MSMEs, lack of proper financial management is a very serious problem of the MSMEs as their survival and success depends largely on the proper management of their financial resources. Finance is regarded as the lifeblood of a business. Finance is needed at every stage of the business development. The continuity and success of any form of business largely depend on the way they managed their finance. There is therefore a need for financial discipline and efficient management of financial resources for the success of a business.

According to the MSME Development Act, 2006, an enterprise engaged in the manufacturing and production of goods whose investment in plant and machinery does not exceed twenty-five lakh rupees is termed as micro enterprises, exceeds twenty-five lakh rupees but does not exceed five crore rupees is termed as small enterprises and exceeds five crore rupees but does not exceed ten crore rupees is termed as medium enterprises. But in the case of enterprises engaged in providing or rendering of services, the investment in equipment does not exceed ten lakh rupees is termed as micro enterprises, exceeds ten lakh rupees but does not exceed two crore rupees is termed as small enterprises and exceeds two crore rupees but does not exceed five crore rupees is termed as medium enterprises. (MSME Development Act 2006).

According to the $73^{\text {rd }}$ round of the

National Sample Survey, during the year 2015-16 there are 633.33 lakh enterprises in the country with a share of $29.20 \%$ to the GDP of the country. Out of the total MSMEs, 630.52 lakhs $(99 \%)$ are Micro enterprises, 3.31 lakh $(0.52 \%)$ are Small while 0.05 lakh $(0.01 \%)$ are medium enterprises. The MSME sector create 12.10 crore jobs where the Micro sector with 630.52 lakh estimated enterprises provides employment to 1076.19 lakh persons, which accounts for around $97 \%$ of total employment in the sector. Small sector with 3.31 lakh and Medium sector with 0.05 lakh estimated MSMEs provides employment to 31.95 lakh $(2.88 \%)$ and 1.75 lakh $(0.16 \%)$ persons of total employment in MSME sector, respectively. (MSME Annual report 2018-19).

The entire eight North-Eastern states collectively have 4.24 lakh MSMEs, which provides an employment generation of about 13.27 lakh people, as against 214.38 lakh enterprises at the national level that provides employment to 501.93 lakh people, which reveals that it is comparatively low at the national level. The units set up under PMEGP stood at 13\% (2015-16), as for MSME, it stood at $17 \%(2015-16)$, and KVIC provided employment to 9.56 lakh artisans (2012). In the context of Manipur, many investors or fund providers like NABARD, NEDFI, SIDBI, IDBI, DIC, KVI Board, KVIC and various Commercial Banks are putting a lot of efforts to help established successful SSIs in various fields. (Ratan, Rajkumar and Meetei, 2019).
The role of MSMEs in the development of the state of Manipur is very important. As on 2015 there were 1078 registered (EM-II filed) MSMEs in Manipur. The total investment in plant and machinery made by these units constitutes Rs. 108.55 crore. The production value (i.e. value of goods and services produced) constitute Rs. 427.9 crore and provide employment to 11,798. Among the MSMEs in Manipur, the Micro and small enterprises contributed the maximum in terms of units, employment and also production value.

\section{STATEMENT OF THE PROBLEM}

The MSME sector has contributed to the Indian economy by providing employment opportunities to a large section of the population. These sectors utilize the locally available resources, using their creativity and innovation. The government have extended various kind of help to support this sector. However, in spite of all the helps extended to them by the government to the sector, they are still facing myriads of problems. Among the many problems faced by the MSMEs, financial management problem is one serious problem which cannot be neglected as the success and failure of the enterprises depend largely on how efficiently they manage their finance. A need to properly look after the finance of the business and to see if they are properly managed is important.

The study therefore seeks to determine the financial management practices followed by the Micro and Small Enterprises in Manipur. The study will also help in identifying the various flaws and problems faced by the entrepreneurs in their financial management work and suggest means of overcoming the difficulties and problems. This will therefore help the sector in taking steps to better equip themselves with the appropriate tools for the efficient management of their financial affairs which will ultimately lead to the success of their business.

\section{REVIEW OF LITERATURE}

Various studies have been made regarding the problems faced by the MSMEs in different parts of the country. However, there are still very few researches related to the financial management problem faced by the Micro and Small Enterprises. Also, no research work has been done in Manipur regarding the financial management practices followed by the MSEs in Manipur.

Ravi (2012) in his study stated that financial management plays a very important role in the survival, growth and development of the smallscale industries. The study further stated that finance is the key input for the sustained growth of the smallscale industries and financial management is the key strategy to achieve this growth. Rahamon (2014) in his study found that there is a strong positive relationship between accounting records keeping and performance of small-scale enterprises. The study 
found out that accounting record keeping increases the chances of business achieving success and provide information for controlling the flow of cash. Accounting records are essential for decision making which invariably affects performance of these enterprises. The study recommended that proper accounting records should be kept for effective financial performance of these businesses. Hepzibah and Justus (2014) in their paper "Accounting practices of MSMEs in the Tirunelveli municipal corporation of Tamil Nadu" found out that in order to enhance the profitability of MSMEs and their continuity, adequate record keeping is needed which will help the entrepreneurs to keep track of their performance. He also stated that accounting information exerts an important influence on the success of MSMEs, therefore it is important to provide complete and relevant financial information needed by entrepreneurs in decision making. Raju (2015) in his study regarding the Financial management practices of the Micro and Small Enterprises in Kerala found out that the financial management practices followed by the MSEs are only firefighting in nature and are learned basically through experience which shows their lack of knowledge regarding the proper financial management of their enterprise. Hendrik \& Quentin (2015) made a study aiming to find the financial management skills necessary for the success of the small and medium enterprises. Among the various financial management practices, the study found out that working capital management and profitability management are very important factor to be kept into consideration for the successful operation of the business enterprises. Ahmad and Sanu (2016) in their study tried to find out the role of MSMEs in the inclusive growth of the economy and also highlights the significant contribution of MSMEs to the Indian economy in terms of industrial production, exports and other economic indicators. The study found out that the MSME sector is promoting inclusive growth in India by means of creating large scale employment opportunities, scaling down regional disparities and bringing backward classes of the people into the main stream of the economy. Gawali and Gadekar (2017) made a study highlighting the significance of better financial management decisions on the basis of efficient financial management practices which are critical and crucial for the survival, growth and profitability of MSMEs. The study concluded that accounting and financial knowledge of the management and their management in the financial affairs of the business helps to a great extent in the success of the business. Satyawati, Lyna and Cahjono (2017) made a study with the objective of developing accounting information system with rapid application development for SMEs to answer whether there is an increase quality of information system in SMEs. The study shows that many of the enterprises do not understand accounting and financial report system. They operate manually and conservatively kept a simple book keeping record. These enterprises do not have a clear and accurate financial report to measure their business growth. Uddin, Biswas, Ali and Khatun (2017) in their study showed that the level of awareness on the importance of Financial Management and accounting system is still very low in SMEs and most managers are not aware of the importance of accounting records. The study also found that in order to keep constant development stable, entrepreneurs need to follow accounting in enterprise and suggested that educating managers and owners on the need to keep accounting record is the best solution. Krishna and Pavithran (2018) made a study to find out the accounting practices of SMEs in Kerala. They found out that most of the enterprises are not aware of the need of accounting practices and they made them only because it is mandatory. They are also not fully aware about the various statements and the benefits of preparing them. The study found out that the enterprises are not using the accounting statements for planning, comparison and decision making and suggest the authorities to take necessary steps to enrich these entrepreneurs about the importance of accounting system and the benefits it could provide for their business. Mekonnen (2019) in his paper Accounting practices of Small and Micro Enterprises in North Shewa Zone, Amahara Regional State of Ethiopia revealed that more than $50 \%$ of the enterprises do not keep their accounting records due to lack of accounting knowledge, higher cost, time waste, labour intensive, etc. Even those who prepare the record still lack accounting knowledge.

\section{OBJECTIVES OF THE STUDY}

The study is done with the main objective of finding out the financial management practices adopted by the Micro and Small Enterprises in Manipur. The specific objectives of the study are listed hereunder:

1) To find out the Financial Management practices of the Micro and Small Enterprises in Manipur.

2) To identify the accounting practices adopted by the MSEs in Manipur.

3) To find out the problems faced by the MSEs while maintaining their accounts and managing their finance.

4) To suggest means of solving the problems faced by the sample enterprises.

\section{METHODOLOGY}

The present study is made by using both primary and secondary sources of data. At first, the available related articles, books, journals, government's periodical and reports, annual report, etc were used to extract the required information regarding the Micro and Small Enterprises. At the later stage, primary data were collected from 90 
enterprises using structured questionnaire prepared by the researcher. The primary data collected using the structured questionnaire were analysed using various statistical tools keeping the objectives in mind.

\section{Limitations of the study}

below:

The various limitation of the study are listed

1) Some of the micro and small enterprises do not maintain any written records at all. Therefore, the information they provide were out of their heads only and lacks reliability.

2) Some enterprises do not want to disclose their information to outsiders for fear of disclosure.

\section{Profile of the enterprise}

The profile of the enterprise that have been considered under the study is presented in Table 1 . It can be seen from the study that $96.67 \%$ of the enterprises are Micro enterprise and only $3.33 \%$ are
Small scale enterprise. Among these enterprise majority $(73.33 \%)$ of them are engaged in rendering service and only $26.67 \%$ units are manufacturing products. Among the 90 units, $93.33 \%$ are soleproprietorship and only $6.67 \%$ are partnership owned. 39 units out of the total are engaged in producing or rendering service of some types, 12 units are electronics, 15 units hardware, 12 units in pharmaceuticals, 6 units are in tailoring and 3 unit each in producing food items and handloom. The Table shows that $20 \%$ of them are uneducated, $26.67 \%$ of them received education till matriculate, $16.67 \%$ of them are under graduate, $26.67 \%$ of them are graduate and $10 \%$ of them have finished their post-graduation. Among these units, $36.67 \%$ of the units are in existence for a period of more than 10 years, $10 \%$ of the units existed for more than 20 years, $20 \%$ of them are in existence for about five years while $33.33 \%$ of them existed for more than 5 years.

Table 1: Profile of the enterprises and entrepreneurs

\begin{tabular}{|c|c|c|c|c|c|}
\hline Nature of Ownership & $\begin{array}{c}\text { No. of } \\
\text { respondents }\end{array}$ & \%age & $\begin{array}{c}\text { Nature of Business } \\
\text { Activity }\end{array}$ & $\begin{array}{c}\text { No. of } \\
\text { respondents }\end{array}$ & \%age \\
\hline Sole-proprietorship & 84 & 93.33 & Manufacturing & 24 & 26.67 \\
\hline Partnership & 6 & 6.67 & Service & 66 & 73.33 \\
\hline Total & 90 & 100 & Total & 90 & 100 \\
\hline $\begin{array}{c}\text { Nature of product or } \\
\text { service }\end{array}$ & & & \multicolumn{3}{|c|}{ Status of the unit } \\
\hline Electronic & 12 & 13.33 & Status & $\begin{array}{l}\text { No. of } \\
\text { respondents }\end{array}$ & \%age \\
\hline Hardware & 15 & 16.67 & Micro & 87 & 96.67 \\
\hline Pharmaceutical & 12 & 13.33 & Small & 3 & 3.33 \\
\hline Tailoring & 6 & 6.67 & Total & 90 & 100 \\
\hline Food & 3 & 3.33 & \multicolumn{3}{|c|}{$\begin{array}{c}\text { Special training in Accounting or Financial } \\
\text { management }\end{array}$} \\
\hline Handloom & 3 & 3.33 & status & $\begin{array}{l}\text { No. of } \\
\text { respondents }\end{array}$ & \%age \\
\hline Others & 39 & 43.33 & Government training & 9 & 10 \\
\hline Total & 90 & 100 & private training & 6 & 6.67 \\
\hline \multicolumn{3}{|c|}{ Educational qualification of the entrepreneur } & no training & 75 & 13.33 \\
\hline Uneducated & 18 & 20 & Total & 90 & 100 \\
\hline Matriculate & 24 & 26.67 & \multicolumn{3}{|c|}{$\begin{array}{l}\text { Use of computer software for Business record } \\
\text { keeping }\end{array}$} \\
\hline Undergraduate & 15 & 16.67 & & $\begin{array}{l}\text { No. of } \\
\text { respondents }\end{array}$ & \%age \\
\hline Graduate & 24 & 26.67 & Using software & 15 & 16.67 \\
\hline Post graduate & 9 & 10 & Not using software & 75 & 83.33 \\
\hline Total & 90 & 100 & Total & 90 & 100 \\
\hline \multicolumn{3}{|c|}{$\begin{array}{c}\text { Employment of qualified accountant/Financial } \\
\text { manager }\end{array}$} & \multicolumn{3}{|c|}{$\begin{array}{l}\text { Knowledge of Accounting/Financial } \\
\text { management }\end{array}$} \\
\hline & $\begin{array}{l}\text { No. of } \\
\text { respondents }\end{array}$ & \%age & & $\begin{array}{l}\text { No. of } \\
\text { respondents }\end{array}$ & \%age \\
\hline Yes & 15 & 16.67 & Yes & 30 & 33.33 \\
\hline
\end{tabular}




\begin{tabular}{|c|c|c|c|c|c|}
\hline No & 75 & 83.33 & No & 60 & 66.67 \\
\hline Total & 90 & 100 & Total & 90 & 100 \\
\hline \multicolumn{2}{|c|}{ Period of existence } & \multicolumn{2}{c|}{ Preparation of financial plan } \\
\hline Years & $\begin{array}{c}\text { No. of } \\
\text { respondents }\end{array}$ & \%age & status & $\begin{array}{c}\text { No. of } \\
\text { respondents }\end{array}$ & \%age \\
\hline Up to 5 years & 18 & 20 & long term & 21 & 23.33 \\
\hline 6-10 years & 30 & 33.33 & medium term & 9 & 10 \\
\hline 11-20 years & 33 & 36.67 & short term & 3 & 3.33 \\
\hline More than 20 years & 6 & 10 & No plan & 57 & 63.33 \\
\hline Total & 90 & 100 & Total & 90 & 100 \\
\hline
\end{tabular}

$40 \%$ of the enterprises have investment in fixed assets up to Rs. $10,00,000,53.33 \%$ invest between Rs.
$10,00,001$ to $25,00,000$ and $6.67 \%$ invested Rs. $25,00,001$ to $2,00,00,000$.

Financial Management \& Accounting

\begin{tabular}{|c|c|c|}
\hline \multicolumn{3}{|c|}{ Knowledge of Accounting/Financial management } \\
\hline & No. of respondents & \%age \\
\hline Yes & 30 & 33.33 \\
\hline No & 60 & 66.67 \\
\hline Total & 90 & 100 \\
\hline \multicolumn{3}{|c|}{$\begin{array}{c}\text { Employment of qualified accountant/Financial } \\
\text { manager }\end{array}$} \\
\hline & No. of respondent & \%age \\
\hline Yes & 15 & 16.67 \\
\hline No & 75 & 83.33 \\
\hline Total & 90 & 100 \\
\hline
\end{tabular}

\begin{tabular}{|c|c|c|}
\hline \multicolumn{3}{|c|}{$\begin{array}{c}\text { Special training in Accounting or Financial } \\
\text { management }\end{array}$} \\
\hline Status & $\begin{array}{c}\text { No. of } \\
\text { respondents }\end{array}$ & \%age \\
\hline $\begin{array}{c}\text { Government } \\
\text { training }\end{array}$ & 9 & 10 \\
\hline Private training & 6 & 6.67 \\
\hline No training & 75 & 13.33 \\
\hline Total & 90 & 100 \\
\hline
\end{tabular}

$33.33 \%$ of the owner/manager of the MSEs does not have any knowledge of accounting or financial management while $66.67 \%$ of them have some knowledge of accounting. 16.67 of the enterprises employ accountant or financial manager while $83.33 \%$ of the enterprises does not employ any accountant or financial manager. Out of the total, 75 of the owners /managers do not receive any form of training in accounting or financial management, while 9 of them receive training from the government and 6 of them receive training from private institutes or training centres.

\section{Capital Structure}

\begin{tabular}{|c|c|c|}
\hline \multicolumn{3}{|c|}{ Source of Capital } \\
\hline Source of Capital & No. of respondents & \%age \\
\hline Owned fund & 57 & 63.33 \\
\hline Borrowed fund & 24 & 26.67 \\
\hline Both owned and borrowed & 0 & 0 \\
\hline Bank loans & 9 & 10 \\
\hline Total & 90 & 100 \\
\hline Working capital requirement \\
\hline Working capital amount & No. of respondents & \%age \\
\hline up to 50,00 & 30 & 33.33 \\
\hline $\mathbf{5 0 , 0 0 1 - 2 , 0 0 , 0 0 0}$ & 24 & 26.67 \\
\hline $\mathbf{2 , 0 0 0 0 1 - 1 0 , 0 0 , 0 0 0}$ & 15 & 16.67 \\
\hline $\mathbf{1 0 , 0 0 , 0 0 1 - 2 5 , 0 0 , 0 0 0}$ & 0 & 0 \\
\hline above 25,00,000 & 6 & 6.67 \\
\hline no working capital & 15 & 16.67 \\
\hline Total & 90 & 100 \\
\hline Financing of Working capital \\
\hline
\end{tabular}




\begin{tabular}{|c|c|c|}
\hline Type of financing & No. of respondents & \%age \\
\hline Owned fund & 51 & 68 \\
\hline Borrowed fund & 9 & 12 \\
\hline Both owned \& borrowed & 15 & 20 \\
\hline Total & 75 & 100 \\
\hline \multicolumn{3}{|c|}{ Method of working capital estimation } \\
\hline Method of estimation & No. of respondents & \%age \\
\hline Through past experience & 18 & 24 \\
\hline By estimating C.A. \& C.L. & 33 & 44 \\
\hline No formal estimation & 24 & 32 \\
\hline Total & 75 & 100 \\
\hline
\end{tabular}

$63.33 \%$ use their owned funds to finance and start their business. $26.67 \%$ of them used borrowed funds from friends and relatives and only $10 \%$ of them took loans from banks to start their business. $33.33 \%$ of the enterprises need working capital up to Rs. 50,000, 26.67\% need working capital between Rs. 50,001-2,00,000, $16.67 \%$ need Rs. 2,00,001$10,00,000,6.67 \%$ need above Rs. $25,00,000$ and $16.67 \%$ keep no working capital. When asked about the sources of their working capital, $68 \%$ of them used their owned funds, $12 \%$ of them use borrowed funds while $20 \%$ of them used both owned and borrowed funds. $24 \%$ of them estimated their working capital needs using their past experience, $44 \%$ used the method of comparing Current assets and Current liabilities and $32 \%$ of them use no formal estimation.

\section{Purchase Management}

\begin{tabular}{|c|c|c|c|c|}
\hline \multicolumn{5}{|c|}{ Frequency of purchase } \\
\hline Frequency & \multicolumn{2}{|c|}{ No. of respondents } & \multicolumn{2}{|c|}{ \%age } \\
\hline Daily & \multicolumn{2}{|r|}{3} & \multicolumn{2}{|c|}{3.33} \\
\hline Weekly & \multicolumn{2}{|r|}{27} & \multicolumn{2}{|c|}{30} \\
\hline Monthly & \multicolumn{2}{|r|}{9} & \multicolumn{2}{|c|}{10} \\
\hline Whenever required & \multicolumn{2}{|r|}{51} & \multicolumn{2}{|c|}{56.67} \\
\hline Total & \multicolumn{2}{|r|}{90} & \multicolumn{2}{|c|}{100} \\
\hline \multicolumn{5}{|c|}{ Proportion of credit purchase } \\
\hline \multicolumn{2}{|c|}{ Proportion of credit purchase } & \multicolumn{2}{|c|}{ No. of respondents } & \%age \\
\hline \multicolumn{2}{|l|}{ up to $10 \%$} & \multicolumn{2}{|l|}{3} & 3.33 \\
\hline \multicolumn{2}{|l|}{$10-20 \%$} & \multicolumn{2}{|l|}{27} & 30 \\
\hline \multicolumn{2}{|l|}{$20-30 \%$} & \multicolumn{2}{|l|}{21} & 23.33 \\
\hline \multicolumn{2}{|l|}{ above $30 \%$} & \multicolumn{2}{|l|}{6} & 6.67 \\
\hline \multicolumn{2}{|l|}{ cash only } & \multicolumn{2}{|l|}{33} & 36.67 \\
\hline \multicolumn{2}{|l|}{ Total } & \multicolumn{2}{|l|}{90} & 100 \\
\hline \multicolumn{5}{|c|}{ Average payment period } \\
\hline Frequency & \multicolumn{3}{|c|}{ No. of respondents } & $\%$ age \\
\hline daily & \multicolumn{3}{|c|}{9} & 10 \\
\hline weekly & \multicolumn{3}{|c|}{18} & 20 \\
\hline monthly & \multicolumn{3}{|c|}{27} & 30 \\
\hline No time bound & \multicolumn{3}{|c|}{36} & 40 \\
\hline total & \multicolumn{3}{|c|}{90} & 100 \\
\hline
\end{tabular}

Only $3.33 \%$ of the enterprise make their required purchase on a daily basis, $30 \%$ of them purchase weekly, $10 \%$ of them monthly and $56.67 \%$ of them made purchase whenever required. Again
$3.33 \%$ made credit purchase up to $10 \%, 30 \%$ of them made $10-20 \%$ of their purchase on credit, $23.33 \%$ of the enterprise take credit between $20-30 \%, 6.67 \%$ took credit above $30 \%$ while $36.67 \%$ of them made 
only cash purchase. $10 \%$ of the enterprises made their payment on a daily basis, $20 \%$ paid weekly, $30 \%$ paid monthly and $40 \%$ have no fixed time bound for paying back their debts. $6.67 \%$ of the enterprises made daily collection of dues, $3.33 \%$ of them collects weekly, $16.67 \%$ of them collects monthly and $73.33 \%$ of them have no specified time period.

\section{Cash management}

\begin{tabular}{|c|c|c|}
\hline \multicolumn{3}{|c|}{ Average amount of cash kept in Business } \\
\hline Average cash kept & No. of respondents & \%age \\
\hline up to Rs. 10,000 & 27 & 30 \\
\hline $10,001-50,000$ & 12 & 13.33 \\
\hline $50,001-100,000$ & 6 & 6.67 \\
\hline above 100,000 & 3 & 3.33 \\
\hline No cash kept & 42 & 46.67 \\
\hline Total & 90 & 100 \\
\hline \multicolumn{3}{|c|}{ Preparation of financial plan } \\
\hline Status & No. of respondents & \%age \\
\hline long term & 21 & 23.33 \\
\hline medium term & 9 & 10 \\
\hline short term & 3 & 3.33 \\
\hline No plan & 57 & 63.33 \\
\hline Total & 90 & 100 \\
\hline \multicolumn{3}{|c|}{ Use of computer software for Business record keeping } \\
\hline & No. of respondents & \%age \\
\hline Using software & 15 & 16.67 \\
\hline Not using software & 75 & 83.33 \\
\hline Total & 90 & 100 \\
\hline
\end{tabular}

\begin{tabular}{|c|c|c|}
\hline \multicolumn{3}{|c|}{ Preparation of Cash Budget } \\
\hline Period & No. of respondents & \%age \\
\hline One month & 15 & 16.67 \\
\hline Two months & 0 & 0 \\
\hline 3 months & 3 & 3.33 \\
\hline No cash budget & 72 & 80 \\
\hline Total & 90 & 100 \\
\hline
\end{tabular}

$30 \%$ of the enterprises kept cash up to Rs.10,000, 13.33\% kept Rs.10,001-50,000, 6.67\% of them kept Rs.50,001-100,000, 3.33\% kept above Rs. 100,000 cash in their business, while $46.67 \%$ of the enterprises did not kept any cash. When asked about the preparation of financial plans, $63.33 \%$ of the enterprises does not prepare financial plan of any form, $23.33 \%$ have long term plans, $10 \%$ have medium term and $3.33 \%$ have short term plans. Out of the total only 15 units used computer in keeping their records or maintaining accounts while 75 of them do not.

\section{Profit and uses of profit of the Business}

\begin{tabular}{|c|c|c|}
\hline \multicolumn{3}{|c|}{ Profitability of the Business } \\
\hline Profitability & No. of respondents & \%age \\
\hline Profit & 90 & 100 \\
\hline Loss & 0 & 0 \\
\hline Total & 90 & 100 \\
\hline
\end{tabular}




\begin{tabular}{|c|c|c|c|c|}
\hline \multicolumn{5}{|c|}{ Uses of Business profit } \\
\hline Uses & No. of respondents & \multicolumn{2}{|c|}{ Total respondents } & $\begin{array}{c}\text { \%age } \\
\text { to } \\
\text { total }\end{array}$ \\
\hline Household purpose & 66 & \multicolumn{2}{|c|}{30} & 73.33 \\
\hline Buying materials & 45 & \multicolumn{2}{|c|}{30} & 50 \\
\hline Re-Invest in Business & 15 & \multicolumn{2}{|c|}{30} & 16.67 \\
\hline Wages/Salaries & 21 & \multicolumn{2}{|c|}{30} & 23.33 \\
\hline \multicolumn{5}{|c|}{ Percentage of Profit retained in Business } \\
\hline \multicolumn{2}{|l|}{ Percentage of profit } & ndents & \multicolumn{2}{|c|}{$\%$ age } \\
\hline up to $10 \%$ & \multicolumn{2}{|c|}{30} & & \\
\hline $11 \%$ to $20 \%$ & \multicolumn{2}{|c|}{6} & & \\
\hline $21 \%$ to $30 \%$ & \multicolumn{2}{|c|}{12} & \multicolumn{2}{|c|}{13.33} \\
\hline Above $30 \%$ & \multicolumn{2}{|c|}{3} & \multicolumn{2}{|c|}{3.33} \\
\hline No profit retained & \multicolumn{2}{|c|}{39} & \multicolumn{2}{|c|}{43.33} \\
\hline Total & \multicolumn{2}{|c|}{90} & & \\
\hline
\end{tabular}

$100 \%$ of the sampled enterprises earn profit. $73.33 \%$ of the enterprises use their profit for their household expenses, $50 \%$ of them used it to buy back the needed materials for their business, $16.67 \%$ of them re-invest and $23.33 \%$ of the enterprises use it for the payment of wages and salaries. $33.33 \%$ of the enterprises retained up to $10 \%$ of their profit in their business, $6.67 \%$ retained up to $20 \%, 13.33 \%$ retain up to $30 \%, 3.33 \%$ retained above $30 \%$ of their profit and $43.33 \%$ does not use retained earnings.

\section{Preparation and use of financial statement}

\begin{tabular}{|c|c|c|c|}
\hline \multicolumn{4}{|c|}{ Preparation of financial statement } \\
\hline Type & No. of respondents & Total & \%age to total \\
\hline trading \& P/L & 21 & 30 & 23.33 \\
\hline B/S & 30 & 30 & 30 \\
\hline CFS & 30 & 30 & 30 \\
\hline WCS & 12 & 30 & 13.33 \\
\hline Budget & 9 & 30 & 10 \\
\hline Business preparing no FS & 48 & 30 & 53.33 \\
\hline
\end{tabular}

$23.33 \%$ of the enterprise prepares Trading and Profit/Loss account, 30\% prepare Balance Sheet, Cash Flow Statement and Budget for their business, $13.33 \%$ prepares Working Capital Statement and $53.33 \%$ does not prepare any financial statement.

\section{SUGGESTION}

1. Majority of the sampled enterprises does not use any form of borrowed funds or loans of any kind for investment in their business which deprived them of the advantage of leveraging.

2. A proper system of working capital estimation is very much needed for these enterprises as majority of them do not employ any formal method.

3. Almost half of the enterprises do not keep any ready cash for their business and many of them also does not maintain proper working capital which are very important components to the business.
4. Many enterprises do not have specified time period for the collection and payment of dues which will be a problem since the true position of the business cannot be known without them.

5. More than half of the enterprises does not prepare any form of financial statement of their business. Financial statements which shows the position, profitability, liquidity, stability, etc. of the business needs to be properly maintained.

6. Majority of the enterprises neither have any formal training regarding the proper management of finance and preparation of accounts. Training should be provided to these enterprises.

\section{CONCLUSIONS}

It has already become a common knowledge that Micro and Small Enterprises are the backbone of the economy. They provide employment 
opportunities, thereby, solving the problems of unemployment. The sector has also contributed a lot in terms of GDP, export, production, etc. MSEs also help to increase the standard of living of the country and also remove the problems of migration from rural to urban areas. For the purpose of this study, a sample questionnaire was formed which was distributed to the targeted sampled enterprises. The data collected were tabulated and then analysed. It was found out from the study that many of the owner/manager of these enterprises still does not have any knowledge of financial management and its importance for their business. The financial management system followed by these enterprises are only firefighting in nature. Many of the owner/manager use their experience as a tool for recording as well as management of their accounts. They also do not have any formal estimation of working capital nor prepare financial plans and budgets. Many of the enterprises do not have proper debt collection and payment system. There is a need to develop a proper system of financial management and accounting record for the micro and small enterprises of Manipur.

\section{REFERENCES}

1. Endang Satyawati, Lyna \& Mardanung Patmo Cahjono. Development of Accounting Information System with Rapid Application Development (RAD) Method for Micro, Small, and Medium Scale Enterprises. Review of Integrative Business and Economics Research, Vol. 6, Supplementary Issue 1. GMP Press and Printing (http://buscompress.com/journalhome.html) ISSN: 2304-1013 (Online); 23041269 (CDROM); 2414-6722 (Print).

2. Firdos Ahmad \& Sahnewaz Sanu. MSMEs and Inclusive Growth in India: Current Scenario and Future Prospective. Intellection: A Bi-annual Interdisciplinary Research Journal, July December, 2016 Vol. IV, No. II ISSN: 2319-8192.

3. Hendrik Wolmarans \& Quentin Meintjes. Financial management practices in successful smack and medium enterprises (SME). SAJESBM Volume 7 (2015).

4. Hepzibah D. Vinsyah Jeyaseeli \& Justus E. Raja (Nov., 2014) "Accounting practices of MSMEs in the Tirunelveli municipal corporation of Tamil Nadu”. Global Journal for Research Analysis, Vol.3 Issue 2 ISSN 2277-8160

5. Krishnan $M$ \& Pavithran $K$ B. Accounting practices of Small and Medium enterprises in Kerala. International journal of basic and applied research www.pragatipublication.com ISSN 2249-3352 (P) 2278-0505 (E) Cosmos Impact Factor-5.86. Received: 8 November Revised: 17 November Accepted: 24 November Index in Cosmos December 2018 Volume 8 Number 12.

6. Mekonnen Gashaw Belete. Accounting practices of Small and Micro Enterprises in North Shewa Zone, Amahara Regional State of Ethiopia. Journal of Investment and Management. Vol.8 issue2, $2019 . \quad$ Pp.40-47. Doi: 10.11648/jim.20190802.12

7. Onaolapo Adekunle Abdul-Rahamon. The Analysis of the impact of Accounting Records Keeping on the Performance of the Small-Scale Enterprises. International Journal of Academic Research in Business and Social Sciences January 2014, Vol. 4, No. 1 ISSN: 2222-6990. URL: $\quad$ http://dx.doi.org/10.6007/IJARBSS/v4il/506.

8. Raju. G. A study on the financial management practices of Micro and Small Enterprises in Kerala. Project Report. Kerala Institute of Labour and Employment, Thiruvananthapuram.

9. Ravi N. Kadam. Financial management: The key strategy for the sustained growth of Small-scale Industries of India. International Journal of Research in Finance \& Marketing. Volume 2, Issue 2 (February 2012) (ISSN 2231-5985)

10. Ravindra B. Gawali \& Ashutosh Gadekar. Financial Management Practices in Micro, Small and Medium Enterprises-An Exploratory Analysis with the help of Literature Review. International Journal of Research in Finance and Marketing (IJRFM) Available online at: http://euroasiapub.org/current.php?title $=I J R F M$ Vol. 7 Issue 6, June - 2017, pp. 45 59 ISSN(o): 2231-5985 | Impact Factor: 6.397 | Thomson Reuters Researcher ID: L-5236-2015.

11. Uddin, R., Biswas, T., Ali, J. and Khatun M. S. Accounting practices of SMEs in Rangpur, Bangladesh. Journal of Business and Financial Management Vol.6 Issue4, 2017 doi:10.5172/2167-0234.1000299 